\title{
Algeria in British Travel Writings (1850-1930): Images and Perceptions
}

\author{
By Mohamed Chamekh*
}

British travellers started their journeys to Algeria in the wake of the Grand Tour. The Industrial Revolution led to a surge in the number of travellers to Algeria, which was for some time a privilege for aristocratic elite. These travellers left a wealth of literature in the form of travel accounts and holiday guides, which included the description of places, representations of the local people, their culture and their religion. This paper argues that most of these writings, namely in the second half of the nineteenth century, were racist and included stereotypes of the majority Arabic population, especially Arab women, and Islam, the majority religion. It confirms the orientalist discourse prevalent in most of the travel literature on the Orient and suggests that this discourse was defensive of colonialism and imperialism. Nevertheless, this paper argues that this racist discourse faded to a certain extent with the increasing commercialization of holidays to Algeria at the beginning of the twentieth century.

Keywords: Algeria, British travellers, holidays, racism, representations, travel writings.

\section{Introduction}

Beginning from the eighteenth century, the British started to travel beyond their shores. This was originally driven by a quest for exploration and discovery, but later for pleasure as well. The first form of offshore travel was the Grand Tour, a journey undertaken by the British elite for education, culture and pleasure to France, Switzerland, Italy, and later to Greece (Towner 1985). This tour especially was a 'precursor' to modern travels (Hunter 2004: 29-30). The Grand Tour did continue into the nineteenth century, but its decline was linked to several factors including the French Revolution (late eighteenth century), the growth of railway networks, cultural changes and the growth of middle class overseas travel (Towner 1985: 300).

In addition to the Grand Tour, Britain was the pioneer of modern tourism. This huge industry was partially a product of the Industrial Revolution, which generated a drive for leisure. This manifested locally with journeys to nearby seaside resorts and abroad with the growth of holidays to overseas destinations. The major breakthrough brought about by the Industrial Revolution came mainly in the nineteenth century with the advent of new means of transport, especially railways, coaches, and steamships. These revolutionized both land and sea transportation and helped British travellers discover new parts of the world, which had previously been terra incognita and accessible only to a privileged aristocratic elite.

${ }^{*}$ Lecturer, Ibra College, Oman. 
This article seeks to answer these main questions: What were the focus of British travel literature in the second half of the nineteenth century and the first quarter of the twentieth century? What kind of image did British travel literature create of local people and places? Did the focus remain the same at the beginning of the twentieth century and why? In order to engage with these inquiries, this research presents a case study of mentions of Algeria, including both its land and people, in British travel writings. The paper has nine sections, including this introduction. The following section presents a literature review and methodology. The next four sections critically engage with some historical trends and theoretical orientations of travels and documentations. These are the importance of holidays to Algeria, tourist attractions as remnants of an empire, travel literature and racism, and travel literature and colonialism. The next two sections specifically address our two primary concerns: the representations of Arab women and the representations of Algeria in travel literature. The final section concludes.

\section{Research Method and Literature Review}

This paper seeks to highlight the subject of the British tourist 'gaze' (Urry 2002) in Algeria. It combines cultural, historical, political and social analysis of the ways that this literature depicted Algeria and the ways that British travellers themselves perceived and represented the place. This study supplements the existing literature on the history of British travellers to Algeria, North Africa and Arabia. This includes, but is not limited to, the works of Perkins (2013), who studied the journey to Algiers as a therapeutic trip, taken to escape the 'inclement' winter weather in Britain. He highlighted the changes in Algiers' tourist infrastructure that were meant to cater mainly to the demands of visitors from Europe in the nineteenth century. Perkins stressed the gradual growth in numbers of British travellers to Algeria and the way this destination began to compete with Spain, Italy and the Riviera as an alternative holiday destination.

Other works that fall within the same category include Manai's (2007) British Travellers in Tunisia, Al Hajri's (2006) study of the representations of Oman in British travel writings and Canton's (2008) general study of Arabia in travel writings; though we should point out that the works of Al Hajri and Canton were conducted from a literary, rather than a historical or cultural, perspective. The work of MacKenzie (2013), however, is of more relevance to this study. This research explores the way travel guides contributed to the imperialist mindset of the British government and elites, as well as the way writers and intellectuals contributed to the advance of British imperialism and dissemination of imperialist thought.

This paper and the broader discussion are also situated within the interdisciplinary field of tourism history. Works in this field are unfortunately underrepresented in the wider literature. In this regard, John Walton (2009) decried the unduly slow recognition of this historical discipline among historians, a problem which stemmed according to Walton from the conservative historical profession. He stated that industries which became 'practically extinct', like the 
British cotton industry; still attract more attention than the history of tourism (Walton, 2013, 3-4). Accordingly, we feel certain that this research addresses a significant gap in the academic sphere.

This analysis of British travel/tourism literature on Algeria is founded on an examination of a wide array of texts in the form of accounts, travel guides, and newspaper articles and publicity initiatives. These sources are useful for understanding the perceptions and representations of foreign lands and people. Some of these, particularly guidebooks, have remained understudied despite their relevance to showcasing mindsets, especially as the compilers of these handbooks went beyond mere descriptions of places and routes to what has been described as historicization (MacKenzie 2013: 20-21). This implies that these travel writings sought to place the target destinations within a wider historical context, especially in relation to the British Empire.

Similarly, Gerald MacLean (2007: 62) considered these texts, though 'unreliable' sometimes, a source of significant insights, particularly where archival materials fail. According to MacLean (2007), this type of literature 'contain[s] otherwise unavailable information that contributes to our understanding of commercial negotiations, political interactions, social life and the formation of national identities in international settings' (MacLean 2007: 62). At the same time, this paper makes use of the extant secondary literature on travel and tourism, in particular in Britain and the Maghreb. These materials, both primary and secondary, can thus be instrumental to understanding the image and discourse used to represent people, culture, religion and place.

This article spans the second half of the nineteenth century and the early years of the twentieth. The choice to focus on this era stems from the historical significance of this era in the history of travel and tourism. It was during this era that modern tourism, according to Hunter (2004: 28), emerged and was even 'perfected' in Western Europe and North America. In Britain, these years saw the beginning of the five-day work week, which came to be referred to as 'la semaineanglaise,' and started to be considered, according to Thompson (1988: 275), an 'Englishman's birthright.' Most importantly, along with the work week development, this era saw the introduction of a holiday from work. Similarly, the steady income generated during the Industrial Revolution helped a new class of people, who used to spend their holidays in seaside resorts in Britain, to travel abroad. Furthermore, the second half of the nineteenth century saw the development of organized tours by Thomas Cook \& Son, which helped an increasing number of people spend holidays in southern European countries, especially Italy, Spain and Greece, and in North African countries, such as Algeria, Tunisia, Morocco and Egypt.

Travel and tourism are considered in this article to be cultural experiences, which lead to the development of images, representations and perceptions of people and their lands. These became the subject of the tourist gaze, who as conceived by Urry (2002) takes in different scenes, landscapes, and environments encountered when travelling. It is the systematic social construction of the tourist experience. 


\section{The Importance of Holidays in Algeria}

The study of British travel to Algeria is significant because it signaled the beginning of a new experience and a new encounter with an 'Other' who was racially, culturally, socially, and religiously different. Algeria - and the Maghreb in general - was the beginning of a new zone where the tourist gaze shifted from the landscape, as was the case in the British seaside resorts, to the people with their culture, religion and social mores. These became in turn the focus of British travel literature (holiday guidebooks, travel accounts and British newspaper materials) in the second half of the nineteenth century and the beginning of the twentieth.

Several factors made the southern Mediterranean and the Maghreb ideal destinations for British travellers. One simple factor was Romanticism, which was partly developed as a reaction against industrialism and the Enlightenment. Aspects of this movement included a predilection for the past, natural beauty, the remote, folk culture and ethnic and cultural origins (Encyclopedia Britannica Online 2018). It was considered one of the motives for a holiday in Algeria and the Maghreb. The lands of the Maghreb were considered 'romantic', and the region in general was taken as the 'land of Romance, mystery and charm' (Cook and Son 1930: 8). Travel to the Southern Mediterranean in general boomed in the nineteenth century as part of a 'widespread Romantic interest in the Mediterranean south' (Arcara 1998: 38). Within the romantic perspective, Algeria was considered part of a 'new' world, which was still immune to the changes of the nineteenth century. This was clear in calls by travellers like Mrs. Greville-Nugent (1894: 2) to visit places like Algeria and the depiction of the place as different in that the past could still be experienced:

I can, if you will take my hand, lead you through these cities where the women walk veiled and trousered, where a strange monotonous music strikes the ear, and where a wealth of wondrously harmonized color delights the eye. Pluck a few flowers with me from the soil of this marvelous Africa, that so, amid the mirk of dire December days in England, you may yet know that beauty and la joie de vivre are not yet wholly things of the past.

The depiction of Algiers by Mrs. Greville-Nugent alluded to barren lands left untouched by the changes wrought by industrialization. Algeria was looked at through the prism of the strange and the exotic. Travellers moved between spaces where people and places were considered as belonging to a different historical epoch; they perceived their Empire as leading a 'civilizing' mission in other parts of the world with different cultures, religions and social traditions. Algeria was in this way a destination where an old world could be discovered.

The journey to Algeria was significant because it signaled a new era in the history of British travel to the Mediterranean, representing the discovery of other parts of the Mediterranean beyond merely the European shores. In doing so, these journeys to the Maghreb represented encounters with different races with a different history, culture, and religion. In this region, Algeria was mostly promoted 
with Tunisia as a single destination. The attractions of both countries, though different by name, evoked this same socio-cultural, religious and historical heritage.

\section{Attractions: The Remnants of an Old Empire}

Examples of travel literature from the second half of the nineteenth century show an emphasis on the Roman heritage of Algeria. Joseph C. Hyam's guide to Algiers (1899: 154) considered Constantine, commonly known as the Cirta of the Romans, the most beautiful of the three provinces of Algeria and traced its history back to Julius Caesar, who formed an important colony there. Similarly, the Roman baths in Algeria, such as Hammam-Meskoutine, were considered to have recuperative benefits for people's health and were still used by hospital patients until 1899 (Hyam 1899: 159). Other Roman cities like Batna, Lambessa and Thimgadis were considered the 'Pompeii of Africa.' Historical towns, which were not necessarily Roman, included Bona, Annaba, and the Kasbah, the citadel which carried this name most probably for its location in the central part of the town or in reference to the old part of the city.

In neighboring Tunisia, almost all guidebooks, newspaper publicity materials and traveller accounts also referred to Roman towns as major attractions, a focus continuing throughout the nineteenth century. The Ladies' Cabinet of Fashion, Music, and Romance, a nineteenth century periodical (1832 to 1861), referred to Carthage and Zaghouan, Roman Zama, as places worth visiting (Nineteenth century UK periodicals 1842: 45). Hyam stressed the importance of Roman history in Algeria and Tunisia. He stated in The Illustrated Guide to Algiers that 'nowhere in the world, outside Italy, are Roman ruins and remains so plentiful as in Algeria and Tunis' (1899: 168). These two colonies were considered a 'large archaeological museum' and a 'perfect library of epigraphically treasure' ("Tunisia in 1885" 1886: 523).

The stress on Roman ruins in Algeria continued into the early twentieth century. In this way, journeys to Algeria could be considered continuations of British travellers' discovery of the Mediterranean, which started with a fascination with Italy because it was seen as a repository of Roman civilization (Arcara 1998), and possibly also as a continuation of the Grand Tour given its aspects of an educational journey. Interest in the Roman heritage of Algeria could be part of a general fascination with the Empire, especially during the Victorian era. In this regard, the British Empire was considered the inheritor of the Roman Empire, and this was partially used as justification for the British imperial presence in different parts of the world, as had been the case in the British fascination with Italy since the Renaissance.

\section{Travel Literature and Racism}

Unlike the fascination with Roman heritage, most of the British travellers' accounts and guidebooks considered Arabs, who form the majority of the 
population in Algeria, a backward and inferior race. The description of Arabs in Algeria was racist in most contexts. This is clear when Playfair (1891: 9) used descriptive terms and phrases like 'so primitive and so filthy in their habits' in reference to Arab citizens. In other instances, the mere description of people also ended in denigration. This was the case with the description of Moors, commonly considered by the French as non-nomadic Arabs, and who were considered by Playfair (1891: 11) to be 'effeminate' in appearance and 'lazy and indolent to excess'. Arabs were considered 'distrustful', lazy and unwilling to learn especially as they were not 'appreciat[ive] the advantages of civilization' (Playfair 1887: 8). Some argued that proper schooling of Arab children could not be accomplished, because it was impossible to implement European standards of 'discipline and cleanliness' (Evans 1868: 172). Evans further considered Algeria a 'champ de manoeuvre that was and should remain backward for the reason that these people were backward by nature' (Evans 1868: 164). Even the festivals of Arabs were considered clear manifestations of their ignorance and backwardness (Wingfield 1868: 18). For example, while in normal circumstances wedding ceremonies were considered exotic and worthy of attending, Evans' account (1868: 50) showed the opposite:

Right glad were we to get home; it was nearly two o'clock, and for the greater part of six hours we had been on our feet in more or less uncomfortable attitudes of curiosity. The heat, the evil odors, scarcely drowned by the heavy scent of mingled rose and musk, the noise, the glare of color and light, was an exhausting "ensemble" that we did not recover all next day. The spectacle, however, was well worth seeing, once in a lifetime, and once only.

In a similar vein, the description of the language of Arabs in Algeria was full of denigration and hatred. Arabic, the main language of the place, was considered 'corrupt, 'vulgar,' and 'contaminated' (Playfair 1891: 12):

The native languages of Algeria are a corrupt form of Arabic, spoken by the Arabs, Moors and Jews... Written Arabic is the same everywhere, but the vulgar Arabic of Algeria is a patois contaminated by words and hybrid expressions borrowed from all the languages of Europe, a relic of the now extinct lingua Franca, mixed with others of Turkish and Berber origin.

Some travellers even exercised attempts at prophecy in reference to the future of the Arabs, ending up with the conclusion that this race could not develop well in the years to come. Those in this school of thought advocated Berber nationalism as a possible option, despite the fact that Berbers and Arabs easily comingled and sometimes, as Davies (1858: 84) put it, it was not easy for outsiders and travellers to differentiate them. 


\section{Travel Literature and Colonialism}

The constant reference to Arabs as a backward race was generally instrumentalized for the defense of the French colonial presence in Algeria. The French were mentioned in most travel writings of the second half of the nineteenth century as being on a civilization and enlightenment mission. In this regard, most British travellers found the French worthy of gratitude for the order they established in the colony (Blackburn 1868, Strahan 1878). In his account of his travels to Algeria and Tunisia, Wingfield (1868: 144-145) concluded that:

God never gave the earth to man that he might leave it uncultivated; and those who fail to cultivate the land in which they live, deserve to be dispossessed. It is surely the duty of civilized nations to point the way, and constrain them by all means in their power to follow it. To prove that the Arab does not fulfill his mission towards the land he lives in, we have but to dip into Government returns, and compare the produce of the native, after all his years of experience, with the shackled efforts of the colonist, who only settled here some thirty years ago.

For Wingfield (1868, ix), it was thanks to the Europeans that Algeria was 'rising gradually, but surely from the mire of barbarism under the influence of Christian and European help.'

Most British travellers to Algeria in the second half of the nineteenth century considered civilization to be synonymous with Christianity. It seems that the terms were intentionally used interchangeably. At the same time, Islam, the predominant religion in Algeria, was considered a source of backwardness and sometimes even cause for disgust and disdain. For example, Evans (1868: 325-326) concluded her account of her stay in Algeria with a clear vindication of the French presence in the Maghreb. Specifically, she invoked, in a missionary tone, the end of Islam as a solution for the local problems. Similarly, the author of Notes in North Africa looked at a group of people reciting prayers in Ramadan with disdain, and another traveller found in a Sufi ceremony a type of 'buffoonery,' and 'a spectacle of degradation' (Windham 1862: 40).

Amos Perry, the American diplomatic and consular agent in Tunis, shared a similar view of the people of Tunisia and considered the French civilizational mission to be a source of prosperity. His comments were embedded with a view of Islam as a source of backwardness:

As Tunisia has shared and is destined to share the general interest for the redemption of the "dark continent" from bondage and barbarism, it is reasonable to expect that it will become in due time pervaded with the spirit of progress that is a distinguishing characteristic of Christian civilization and thus come to act a part in history more elevated than that enacted under Roman or Carthaginian rule. (Perry 1891:104) 
The discourse on European colonialism stood in stark contrast to the discussions of the influence of Arabs on the Kabyles culture and religion, which was considered the result of the 'sword of the Arab invader' (Strahan 1878: 61). In this way, there was a double standard concerning the notion of colonialism. When the colonizer was European, he was considered a source of enlightenment and civilization, but when the colonizer belonged to another race or region then he was considered an invader.

In general, British travel writings of the second half of the nineteenth century included a clear defense of colonialism and imperialism. In this regard, travel, ostensibly a leisure activity, became, as F. Robert Hunter (2004: 26) put it, 'inseparable' from colonization. The claims by the occupying powers of a mission to civilize these people were given legitimacy by tourists, and they shared the same perceptions of the local people, who were mostly considered unruly, backward, and especially in need of this civilizing mission from the 'Occident.' This description confirms the discourse of orientalism prevalent in travel literature about Algeria. Edward Said's thesis of Orientalism is relevant to the European perceptions of Algeria and Tunisia, two territories considered sites of 'disorders and decadence' (Said 1979: 233), mainly because of Islam.

What is interesting in the vindicatory colonial discourse is the fact that these travellers were not 'constructing an imperial identity for Britain' (Arcara 1998: 123). Rather, it was for France, providing a justification for the superiority of one race and region over another. This discourse echoed the historical changes of the era as the second half of the nineteenth century and the early twentieth century saw the partitioning of territories, especially in Africa, between Great Britain, France, and to a lesser extent Italy, Germany, the Netherlands and Belgium. In this regard, this travel literature was an expression of the spirit of the age which saw, according to Eric Hobsbawm (1987: 59-60), the division of the world into the strong and the weak, the advanced and the backward. It was in these days that imperialism appeared to describe and justify this 'novel phenomenon.' This is the 'myth', as described by Mackenzie (2013: 20-21), which these holiday guides and travel accounts sought to disseminate and which consisted, in this case, of the superiority of one race over the others. In brief, the travel writings of this era introduced descriptions of Arabs in Algeria as inferior and backward. As such, they were meant to justify colonialism and at the same time to consider backwardness as an innate racial problem unrelated to colonialism itself.

\section{Arab Women in Travel Literature}

Within the same discourse portraying Algerian people as backward, Arab women were portrayed as creatures of inferior status. Barbara Leigh Smith Bodichon (1858: 92), a mid-nineteenth century feminist, referred to Algeria as the 'prison of the Eastern women.' Similarly, Playfair (1891) decried the situation of Arab women in Muslim societies in general. He stated in this context that 'the female in Arab Society occupies a situation similar to what she fills in all 
Mohammedan countries; amongst the rich she is the slave of her lord's pleasure, amongst the poor she is the household drudge' (10).

Algerian women were mostly considered subdued and ill-treated. For example, the 1899 Guidebook of Algiers considered the situation of Algerian women to be very pathetic:

Although slavery has been practically abolished among the Arabs, the life of an Arab woman is, in most cases, a very sad one, for when married she is considered by her husband inferior to him and thus treats her as his slave, not as his wife, a position to which she easily becomes reconciled. Her duties include all that a servant can perform for a master, and her privileges are extremely rare... Among the lower class Arabs, it is the wife who does most of the hard work, even in the fields, and in this matter, is looked upon as a domestic animal toiling for its master and while she is so hard at work, her husband will be enjoying his leisure squatting outside his hut, or gourbi, drinking coffee, smoking his cigarettes, playing draughts or otherwise whiling away the time. (Hyam 1899: 26).

This description of the fate of a subdued Arab woman was followed by a section contradicting her situation as inferior by describing her extravagant dress, jewelry and dyes. The Arab women's dress for instance was considered 'singularly interesting and never fails to be attractive to strangers' and her jewelry was considered a 'passion' (Hyam 1899: 28).

Algeria's Muslim society was considered the source of the backwardness of women. In the account of Lewis Strange Wingfield, women were considered a mere commodity regardless of their educational background. This was the result of 'Mussulman prejudice,' which relegates women to the status of a mere commodity. Wingfield (1868: 8) wrote:

Arab women are by no means "stupid", as is proved by the success of an embroidery school established by a French lady exclusively for Arab girls. They are perfectly capable of receiving instruction and education, but once returned to the bosom of their families, their improved condition only becomes an additional weight of misery to them; for, according to Mussulman prejudice, a woman is a thing, and nothing but a thing, whatever may be her education or the powers of her intellect.

Similarly, Hyam's Illustrated Guide to Algiers links the condition of women in Algeria to Islam. This guide allotted large sections to the description of the fate of Arab women, who were considered victims and at the same time manifestations of a backward society (Hyam 1899: 26). Surprisingly, this guidebook referred to the improvement of the conditions of Algerian women with the French occupation. Yet, the same guidebook ends with this consideration of Arab women as slaves: 
Although slavery has been practically abolished among the Arabs, the life of an Arab woman is, in most cases, a very sad one, for when married she is considered by her husband inferior to him and he thus treats her as his slave, not as his wife, a position, however, to which she easily becomes reconciled. Her duties include all that a servant can perform for a master, and her privileges are extremely rare... Among the lower class Arabs, it is the wife who does most of the hard work, even in the fields, and in this matter, is looked upon as a domestic animal toiling for its master; and while she is so hard at work, the husband will be enjoying his leisure, squatting outside his hut, or gourbi, drinking coffee, smoking his cigarettes ,playing draughts - a game of which the Arab is very fond-or otherwise whiling away the time, and caring little or none at all for his wife or the manner in which she labors, so long as she does the work ... Her position is so inferior to that of her husband that she is not even allowed to eat with him, but serves him at table and remains standing whilst he enjoys the meal that she has cooked. (Hyam 1899: 25-26).

The consideration of Algerian women as slaves was used to justify colonization on the grounds that the situation of women was so deplorable and miserable external, emancipatory power was needed to liberate them. According to Irene Zempi and Neil Chakraborti (2014: 7-8), the 'liberation' of Muslim women became the justification for colonialism, with the image of the subjugated Muslim woman in need of rescue by Western men being used to legitimate the build-up of the French and British colonial empires. For example, the author of Algiers in 1857 referred to the role of the French mission in Algeria in the improvement of the condition of Algerian women, mentioning specifically the provision of better healthcare for women, (Davies, 1858, 84). The French were also praised for getting Algerian women out of their lifelong seclusion (Windham 1862: 16). Similarly, Strahan (1878: 56) referred to the role played by the French in improving the condition of Algerian women. He specifically discusses the rights of Algerian women, especially when a case of mistreatment was brought to their attention.

The British travellers' 'representational apparatus' of women in Algiers and other parts of the Maghreb was in tune with the official discourse that legitimated the colonization of Africa on social, economic, religious and even on racial grounds which was clear in the description of Blacks. For example, in Algiers in 1857, Davies (1858: 146) described what he referred to as 'negroes' fetes, which he found both monotonous and strange enough to capture his, as well as other Europeans, attention:

The negroes danced in rings to the monotonous music of the tom-tom: the ox was slain, and his blood sprinkled on the faces of those engaged in the sacrifice: then the negroes danced again; and as the music grew livelier, the dance became faster and faster, till at length, in a frenzy, some cast themselves into the sea, while others rushed in madly to save them. After this 
exhibition, the ox, roasted whole, was the piece de resistance in the feast that followed.

The same applied to Evans's description (1868: 44) of black women dancers, which was full of contempt and to a certain extent racial bias. Yet even in this context, and despite the denigrating rhetoric used in reference to Blacks, the English considered themselves their emancipators. For example, Sir Thomas Wemyss Reid (1882), in his account of his journey to Tunis, stressed the role played by the English in 'liberating' blacks from slavery. 'Men now living in Tunis', he stated, 'can remember the time when slaves were sold here; it was indeed the father and the predecessor of the present English council, the late Sir Thomas Reid who succeeded in putting an end to the abominable traffic' (Reid 1882: 77).

It is true that the socio-economic conditions in the Maghreb and Africa in general were degenerating in the nineteenth century, but the description of Algerian society, which also applied to other parts of the Maghreb, seems full of bias and serves to justify the assumed superiority of one race, religion and culture over another. Therefore, it is reasonable to say that travel literature served colonial interests as the common purpose of guidebooks in general is to guide people through unknown territories and to describe attractions and places of interest. This was not, however, the case with most of the travel writings on Algeria, where the focus was on 'backward' Muslim societies and 'subjugated' women, as well as the civilizing mission of the French.

The French were considered the liberators of Arabs in Algeria and Tunisia from the Turks. French colonization, though clearly resulting in the exploitation and subjugation of local populations, was considered by many, for example by Greville-Nugent (1894) in her account of her travel to Tunis, to constitute a civilizing mission. This was especially the case in light of the economic opportunities it created, its establishment of public order and the new systems, such as police and courts, introduced, despite the fact that the role of the latter (the police and the courts) was of the 'blue locusts' type, as described by Storch and Engels (1975) in their reference to the use of the police by the British aristocracy. In general, the French role was highly esteemed. In a long accolade describing the French mission, Greville-Nugent stated:

What has France done for the Arabs of this province? For one thing she has delivered them from the bondage of the Turks, who were indeed cruel taskmasters. En plus, she has given them regular employment in vineyards, orange gardens, date groves, railways, shipping yards, and a thousand commercial enterprises. She has given them sanitation, police and civilization in so far as it can be combined with their religious code. She has given them French courts of law where their grievances can be redressed without bribes to corrupt effendis. Their property is secured to them by the chefs' des bureau Arabes, officials who, to their Knowledge of European jurisprudence, have added a profound study of language and customs with which they have to deal, and whose duty it is to inquire into and adjust all disputes between rival 
tribes, etc. All this and much more have the French given to the native population, and the native population seem to be duly submissive and grateful. (1894: 128-129).

The same order was established in Algeria according to Greville-Nugent, but the only difference was the association between Islam and the local problems. 'Today,' she stated, 'all is outwardly smiling and prosperous; old grudges dead, apparently, and buried deep', but according to Greville-Nugent the only problems left unsolved emanated from the nature of Islam as a religion (Greville-Nugent 1894: 130). This discourse was typically orientalist, particularly in its association between Islam and the problems in the region. According to Manai (2016), these travel writings contributed to misconceptions about Islam that continued for more than a century.

This perception of Islam in Algeria, the condition of women in Arab society, and the backwardness of the local people is part of an overall perception of the Maghreb as a racially, culturally, religiously and economically inferior environment, especially when juxtaposed to a racially, culturally and economically superior Occident. This made these writings a huge reservoir of stereotypes, misconceptions and misrepresentations of the local people. Algeria could be considered another type of liminal space (Shields, 1988: 192), where the order and decency of a western society was not existent. It was an environment on the margin where enlightened Christendom was missing and where people from a society that had witnessed the Industrial Revolution and all its impacts on the economy, politics, and the sociocultural environment came in contact with people from a pre-industrial cultural and political order.

\section{Algeria in Travel Literature (1900-1930)}

The introduction of Thomas Cook \& Son holiday tours to Algeria brought changes in the content of travel writings, particularly in holiday guides prepared by this company. The introduction to Cook's Guide to Algeria and Tunisia (1904) signaled a change in the purpose of guidebooks at the beginning of the twentieth century. They were now to be mainly informative. This guidebook and other Cook's guides started with the major attractions, such as the weather (widely marketed especially for invalids) and historical cities, and tourist infrastructure, such as hotels as the major attractions of Algeria. The introduction to Cook's 1904 guidebook of Algeria and Tunisia reads as follows:

The climate of Algeria and Tunisia is unique, and eminently adapted to the comfort of those who suffer; the picturesque aspect of Arab life, of the white cities with their narrow streets; the historical souvenirs of these lands that from time to time have been subject to the Kings of Numida, to the Roman Emperors, to Arab, Spanish, and Turkish conquerors, all this offers to the learned and enquiring traveller a study of past civilisations, and the the 
ordinary tourist the enjoyment of picturesque and beautiful country. (Cook and Son 1904: iii)

Cook's Guidebooks focused mostly on the routes, history, places to visit, means of transport, affordability of holiday tours, and hotels. It was clear, for example, from the preface to Cook's Guidebook to Algeria and Tunisia (1908) that the focus had shifted to place rather than the people and their religion. The guide book was informative and revealed a clear emphasis on the information needed by prospective tourists to Algeria and Tunisia. A number of new hotels were advertised in guidebooks and newspapers of holidays in Algeria. These included the Grand Hotel, Hotel de France, Royal Hotel, The Hotel Continental, Hotel St. George Grand Hotel de Paris, and Hotel Victoria. In Tunis, there were just two first class hotels - Hotel de Paris and Imperial. Hotels grew in number and spread around different parts of Algeria and Tunisia. To the descriptions of these attractions, Cook added mentions of the cost, which was considered affordable in comparison with other holiday destinations like Madeira or the Canary Islands. Thomas Cook \& Son played a pivotal role in this change (Travel in Comfort 1909: 7). The fare was 60 Guineas, around $£ 6,210$ in today's money. This shows that this journey was mainly reserved for upper working classes and middle classes who were privileged to be able to spend what were half the average annual earnings in the late nineteenth century.

Other tour operators also advertised holiday packages to Tunisia and Algeria. For example, George Lunn's tours advertised Italy, Paris, Algiers, Tunisia, and Sicily in one 'escorted' holiday package (George Lunn's Tours Italy 1923: 674). Other tours included Nice, Italy, Sicily, Malta, Tunisia, Algeria, Gibraltar, Morocco, Spain and Portugal, returning finally to Southampton in England. The cost of the tour, at $£ 60$, remained the same in comparison with the early years of the twentieth century (B. \& N. Line Royal Mail Ltd. 1928: 370). Promotions also changed to include hotels and the tourist infrastructure at destinations.

Winter holidays were a major aspect of holidays in Algeria. The 1920s and early 1930s saw a focus on the weather, landscape and scenery. The most striking change, however, which was concomitant with the growth of organized tours to Algeria and Tunisia, was the reduced emphasis on local society, religion, women and social mores in holiday guide books, traveller accounts and newspapers. References to Islam as a major cause of the social problems became fewer in comparison with the holiday literature of the second half of the nineteenth century and references to cities, considered emblematic of Islam, like Kairouan were free of religious prejudice. For example, John Prioleau, a British traveller, found Kairouan 'worth seeing' and at the same time a 'perfectly glorious little place ... almost unique' (Prioleau 1921: 5). As it might appear from this brief description, the orientalist discourse, which characterized the second half of the nineteenth century, started to fade in the first quarter of the twentieth century.

The emphasis on the weather, the historic attractions and the tourist facilities could have stemmed from the increasing commercialization of holidays to the Maghreb and the beginning of mass holidays to this region, as well as the changing socio-economic profiles of visitors who belonged mainly to the upper 
working classes. This journey ceased to be an upper and middle class privilege, and instead an increasing number of the working class started to take part in journeys to the Maghreb, especially those organized by Thomas Cook \& Son, George Lunn and TRANSTAT. This was a major change in the 1920s, which signaled the growing accessibility of holidays to Algeria and other parts of the Maghreb, especially Tunisia and Morocco. Holidays to this region came to be considered part of a journey that suited 'every purse' (The Times 1930: 20), which had not been the case in the second half of the nineteenth century and the early years of the twentieth century.

In a similar vein, the content of travel literature saw changes on the other side of the Atlantic, especially when we compare the experience of Amos Perry, the American diplomatic and consular agent in Tunis and Algeria, with the experience of Francis Miltoun, an American author and traveler. In the Land of Mosques \& Minarets (Miltoun 1908) heralded a change in perception, in particular towards women and religion in the Maghreb. Instead of contending with the impressionistic view common in most travel accounts of the second half of the nineteenth century, Francis Miltoun (1908) provided in his account of his journey to Algeria a holistic view of Islam. He concluded that 'one religion is not so very different from another after all. It is only a matter of belief, not of the mode of expressing one's adherence to that belief' (Miltoun 1908: 85). He even highlighted the positive aspects of Islam. 'The Mohammedan's religion,' he stated, 'is a very plausible and a very well-working one. He has no false gods or idols. That's a good thing of itself. And superstition plays a very small part therein' (Miltoun 1908: 91). This is a major change in comparison with the second half of the nineteenth century when most of the travellers satirised different aspects of Islam that led to major misconceptions about the religion, the people and even the place.

Miltoun (1908) provided an in-depth analysis of Islam and women in Arab society and analyzed both the advantages and disadvantages of being an Arab and a Muslim woman. He referred to the observations of other travellers, such as Edmond de Amicis, who found that "no Arab dares lift an offending hand against a woman in public. 'No Arab soldier, even in the tumult of attack, would think of maltreating even the most insolent of womankind.' He referred to the fact that many Europeans 'have been known to do both these things' (Miltoun 1908: 88). Francis Miltoun gave an example of the respect conferred on mothers as a cogent example, which refuted the commonly bleak picture of the condition of women in Algerian society plaguing the travel literature of the second half of the nineteenth century:

In her cloister, or to be more exact, in her boudoir, the Arab woman, and particularly the mother, receives the most respectful homage and solicitude from the entire household. According to the Koran the children are admonished to respect the persons of those who bore them, and a verbal declaration of the Prophet is set down as: "A child may gain Paradise only by following in the footsteps of its mother." (Miltoun 1908: 88) 


\section{Conclusion}

British Holiday writings of the second half of the nineteenth century were mostly characterized by a focus on local society and religion. Most of the travel accounts and guidebooks stereotyped and satirized Algerian people and Islam and stressed the so-considered pathetic conditions of Algerian woman. In so doing, most of these writings also sought to defend the French colonial presence in light of the 'civilizing' mission they embarked on in Algeria.

This orientalist discourse, which characterized the travel literature of the second half of the nineteenth century, started to fade in the early years of the twentieth century. Instead, there was a focus on the landscape and tourist infrastructure as major attractions of holidays in Algeria. This does not mean that references to women and Islam disappeared, but they were fewer in frequency. The exception was the travel accounts prepared by missionaries, whose stand as far as Islam and Arabs were concerned continued to be extreme, racist and sometimes fanatic.

These shifts in discourse were encouraged by the growing tourism to this region. The major attractions promoted for these overseas holiday destinations stood in stark and appealing contrast to the popularity and local interest in seaside resorts in Britain. Unlike the stress on seaside resorts as major destinations at the local level, the emphasis on holidays in Tunisia and Algeria was on the desert, monuments and Islam. These offered chances to experience places and histories deemed unique. Accordingly, the orientalist and stereotypical travel writings of the late nineteenth century required changes in correspondence with increased publicity and desirability of holidays to the region.

\section{References}

Nineteenth Century UK Periodicals (1842) “A day at Carthage.” The Ladies' Cabinet of Fashion, Music, and Romance. London: Rogerson and Tuxford.

Al-Hajri H (2006) British Travel-writing on Oman: Orientalism reappraised. Bern: Peter Lang.

Arcara S (1998) Constructing the south: Sicily, Southern Italy and the Mediterranean in British culture, 1773-1926. PhD dissertation. University of Warwick.

B. \& N. Line Royal Mail Ltd (1928) Illustrated London News, March 03,1928.

Blackburn H (1868) Artists and Arabs: Or, Sketching in Sunshine. London: Sampson Low, Son, and Marston.

Bodichon B (1858) Guide Book: Algeria Considered as a Winter Residence. London: Englishwoman's Journal Office.

Canton J (2008) From Cairo to Baghdad: British Travel Writing on Arabia, 1882-2003. $\mathrm{PhD}$ dissertation. University of Essex.

Cook T (1904) Cook's Practical guide to Algeria and Tunisia. London: Thomas Cook \& Son.

Cook T (1908) Cook's Practical guide to Algeria and Tunisia. London: Thomas Cook \& Son.

Lewis DEW (1858) Algiers in 1857: Its Accessibility, Climate, and Resources Described with Especial Reference to English Invalids. Also Details of Recreation Obtainable in 
Its Neighborhood, Added for the Use of Travellers in General. London: Longman, Brown, Green, Longmans, \& Roberts.

Encyclopedia Britannica (2018) Romanticism. Retrieved from https://bit.ly/2xJJ3Pw.

Lloyd E H (1868) Last Winter in Algeria. London: Chapman \& Hall.

The Times (1930) French Line November 28.

Illustrated London News (1923) George Lunn's Tours Italy. October 13.

Greville Nugent E (1894) A Land of Mosques and Marabouts. London: Chapman \& Hall, Ld.

Hobsbawm E (1987) Age of Empire: 1875-1914. New York: Vintage Books.

Hunter F R (2004) Tourism and Empire: The Thomas Cook \& Son Enterprise on the Nile, 1868-1914. Middle Eastern Studies 40 (5): 29-30. doi: 10.1080/00263200420002 65666.

Hyam J C (1899) The Illustrated Guide to Algiers. A Practical Handbook for Travellers. Englishwoman's Journal Office.

MacKenzie J M (2013) Empire Travel Guides and the Imperial Mind-set from the MidNineteenth to the Mid-Twentieth Centuries. In The British Abroad Since the Eighteenth Century 2: 116-133. London: Palgrave Macmillan.

MacLean G (2007) The English Abroad: Travellers, Traders, Captives and Colonists in the Ottoman Mediterranean. In Looking East, 62-96. London: Palgrave Macmillan.

Manai A (2007) British travellers in Tunisa, 1800-1930: A History of Encounters and Representations. Tunis: Centre for University Press.

Manai A (2016) Islam and Muslims in British Travel writing on Tunis in the nineteenth and early twentieth centuries. Historical Yearbook 13: 47-56.

Miltoun F (1908) In the Land of Mosques \& Minarets. Boston: Sir Isaac Pitman.

Perkins K J (2013) So Near and Yet So Far: British Tourism in Algiers, 1860-1914. In The British Abroad Since the Eighteenth Century 1: 217-235. London: Palgrave Macmillan.

Amos P (1891) An Official Tour along the Eastern Coast of the Regency of Tunis. Washington: Standard Printing Company.

Playfair, Lambert R (1887) Handbook for Travellers in Algeria and Tunis. London: John Murray.

Playfair, Lambert R (1891) Handbook for Travellers in Algeria and Tunis. London: John Murray.

Prioleau J (1921) City of Eighty Mosques.In Daily Mail.

Reid T W (1882) The Land of the Bey. Being Impressions of Tunis under the French. London: Sampson Low \& Co.

Said E (1979) Orientalism. New York: Vintage.

Shields R (1988) Images of Spaces and Places: A Comparative Study, $\mathrm{PhD}$ dissertation. University of Sussex.

Storch R D, Engels F (1975) The Plague of the Blue Locusts: Police Reform and Popular Resistance in Northern England, 1840-57. International Review of Social History 20 (5): 61-90. doi: 10.1017/S0020859000004843.

Strahan L G S (1878) Walks in Algiers and Its Surrounding. London: Daldy, Isbister\& Company.

Thompson F (1988) The Rise of Respectable Society: A Social History of Victorian Britain, 1830-1900. Cambridge: Harvard University Press.

Cook \& Son (1930) The Times.

Towner J (1985) The European Grand Tour, PhD dissertation. University of Birmingham. Travel in Comfort (1909) Daily Mail.

Tunisia in 1885 (1886) Proceedings of the Royal Geographical Society and Monthly Record of Geography 8 (8): 523. 
Urry J (2002) The Tourist Gaze. London: Sage.

Walton J K. (2013) Histories of Liminality on the Coast, 3-4.

Walton J K (2009) Welcome to the Journal of Tourism History. Journal of Tourism History 1 (1):1-6. doi: 10.1080/17551820902739034.

Windham W G (1862) Notes in North Africa: Being a Guide to the Sportsman and Tourist in Algeria and Tunisia. London: Ward and Lock.

Wingfield, L S (1868) Under the Palms in Algeria and Tunis. London: Hurst and Blackett.

Zempi I, Neil C (2014) Constructions of Islam, Gender and the Veil. In Islamophobia, Victimisation and the Veil, 6-22. Palgrave Macmillan UK. 
